\title{
The Forest Research Institute, Dehra Dun, India.
}

By Alex. Rodger, Inspector-General of Forests, India.

$\mathrm{T}$ HE history of forest research and education in forestry in India has been intimately connected with Dehra Dun for the last fifty years, as the first college for training Indians in forestry was started there in the year 1878. Dehra Dun was chosen because of its favourable position for the study of two important types of Indian forests, those where Sal (Shorea robusta) predominates, and the coniferous forests of the Himalayas, which are all well represented close to Dehra Dun, and also because of its delightful situation and (during most of the year) its favourable climate.

About twenty-five years ago it was realised that the proper conservation, development, and utilisation of the magnificent State forests in India (covering 250,000 square miles, or 23 per cent of the total area that considerable expenditure on research in forestry, calculated to improve the methods of growing, developing, and exploiting the forests, was justified.

The first buildings used for research were, as usually happens in such cases, small places, situated wherever anything suitable could be obtained. In 1913, however, a proper building was constructed, containing laboratories, offices, and museums for the sylviculturist, economist, and entomologist. The botanist and chemist were housed in separate buildings on the same estate. This was the first attempt to concentrate forest research in proper buildings, and it was soon realised how useful the concentration was. With modern development of forestry in the field, work increased rapidly, and in 1920 much more ambitious plans were drawn up. These comprised a large

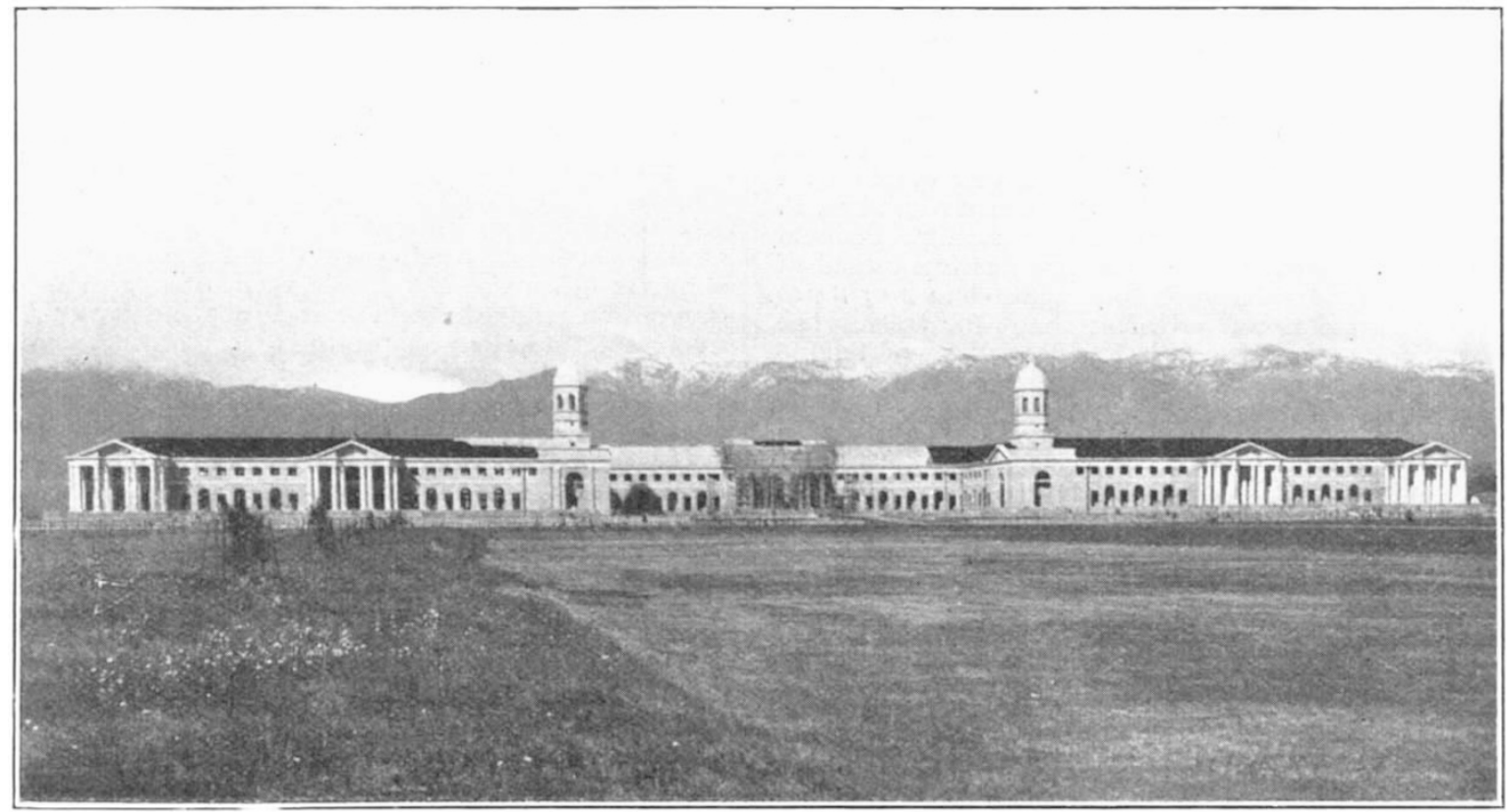

FIG. 1.- Main building of the Forest Research Institute, Dehra Dun, with the Himalayas in the background.

of the country) depended on organised research, and a start was made in a small way by the appointment of a forest zoologist, who began work on insect pests in 1900. The outlook on research of professional forest officers has changed very much since that day. It is recorded that an officer high up in the department was indignant because the first research officer had produced no literature within a year after his appoint. ment. Public opinion rapidly matured, and about twenty years ago four other research officers were appointed. It was considered at that time that the conduct of research in forestry in India should be divided into five branches, covering sylviculture, economy, botany, entomology, and chemistry, and this arrangement has lasted to the present day.

Including the area under forest in Indian States, about one quarter of the Indian Empire is covered with forest, and the net revenue in British India in the year 1925-26 was two million pounds, gross receipts amounting to $4 \frac{1}{2}$ million pounds and expenditure to $2 \frac{1}{2}$ million. The surplus has more than doubled during the last twenty years. It will be recognised building with workshops, electric plant, stores, insectary, and residences of different grades, all situated on an estate of 1200 acres which was acquired close to Dehra Dun. The main building (Fig. 1) will be completed in 1928. In this fine building there is ample accommodation for the five branches, and possibly part of the Forest College will also occupy it. The new building contains six museums, with floor space of 26,000 square feet, a convocation hall with 6000 square feet, and numerous laboratories and offices, which have a floor space of about 63,000 square feet. The architect is Mr. C. G. Blomfield, of Dalhi.

The aim of the staff of the Forest Research Tnstitute is to find out and publish everything about the forests and forest products of India which will be of use to the public and to the forest departments of the various provinces and of the Indian States. Information when collected is published at once and is available to any one, and no small part of the time of the controlling staff is taken up in answering inquiries from every conceivable source. Most of these inquiries come, of course, from India, but there is

No. 3065, VoL. 122] 
scarcely any part of the world with which the staff is not in communication, and inquiries are regularly received from almost every country where forestry and forest products are of any importance.

The cost of the Forest Research Institute is entirely met by the Government of India, the annual expenditure being about $£ 70,000$. The total capital cost of the new Forest Research Institute, which is not yet quite completed, will be about $£ 750,000$, surely a record for forest research. The majority of the controlling staff is composed of forest officers deputed from their provinces, but there is a number of specialists who deal with subjects such as timber testing and kiln seasoning. The total staff of the Forest Research Institute and College comprises 35 controlling and 260 subordinate members. The Institute is constantly visited by forest officers and others from every part of the world, and some of those visitors stay for a considerable period, and take a course in one or more of the special lines dealt with. The work done by the various branches is of course closely related, and constant consultations take place between the branch officers, but it will be convenient to describe the scope of the work done under the various heads.

\section{Sylviculture.}

This, although not the largest, is the senior branch, as is proper in a Forest Research Institute. Prof. Troup, who is now Director of the Imperial Forestry Institute at Oxford, was the pioneer in modern scientific sylviculture in India, and he embodied the results of his observations in his three fine volumes "The Sylviculture of Indian Trees," published by the Clarendon Press in 1921. Since Prof. Troup left Dehra Dun the branch has developed considerably, and the work of the Imperial sylviculturist is co-ordinated with that of a number of provincial sylviculturists in $\mathrm{Ma}$ dras, Burma, Bengal, etc. Sample plots to determine the best method of growing important species, and to obtain figures for volume, increment, etc., have been established in many forests throughout India and Burma, and the working up of the statistical data obtained from all these sample plots is undertaken at Dehra Dun. Yield and volume tables for important species are regularly published, and a great deal of work is done on the germination and development of the seeds of forest trees. Working plans are examined for provinces, and all sylvicultural matters constantly discussed with local officers.

Model plantations of several important species are being made on the estate at Dehra Dun close to the Forest Research Institute, partly with the view of making them into demonstration areas for the students at the College, which is under the same president as the Forest Research Institute. The sylviculturist can rarely, of course, show such immediate results as the forest economist, but, with the present rapid additions to our knowledge of how to treat the forests of India, the value of the forests as a great asset of the country will increase steadily. Sustained scientific management in the case of valuable property which does not come to maturity for 100 or 150 years is, of course, of the utmost importance.

\section{ECONOMY}

Forest economy or utilisation has developed at the Forest Research Institute more than any other branch, and has in fact been divided already into sections, covering wood technology, timber testing, wood preservation, kiln seasoning, paper pulp, minor forest products, and wood working. The workshops for this branch are separate from the main building and were constructed before it. This branch is in intimate relation with the most important users of timber and forest products, for example, the railways and the Gun Carriage Factory, and is continually giving advice to these and to other commercial and semi-commercial concerns. To ensure continuity of experimental work, a triennial programme is passed by the InspectorGeneral of Forests and the different inquiries are carried on under the provisions of printed projects in which the lines of research are laid down.

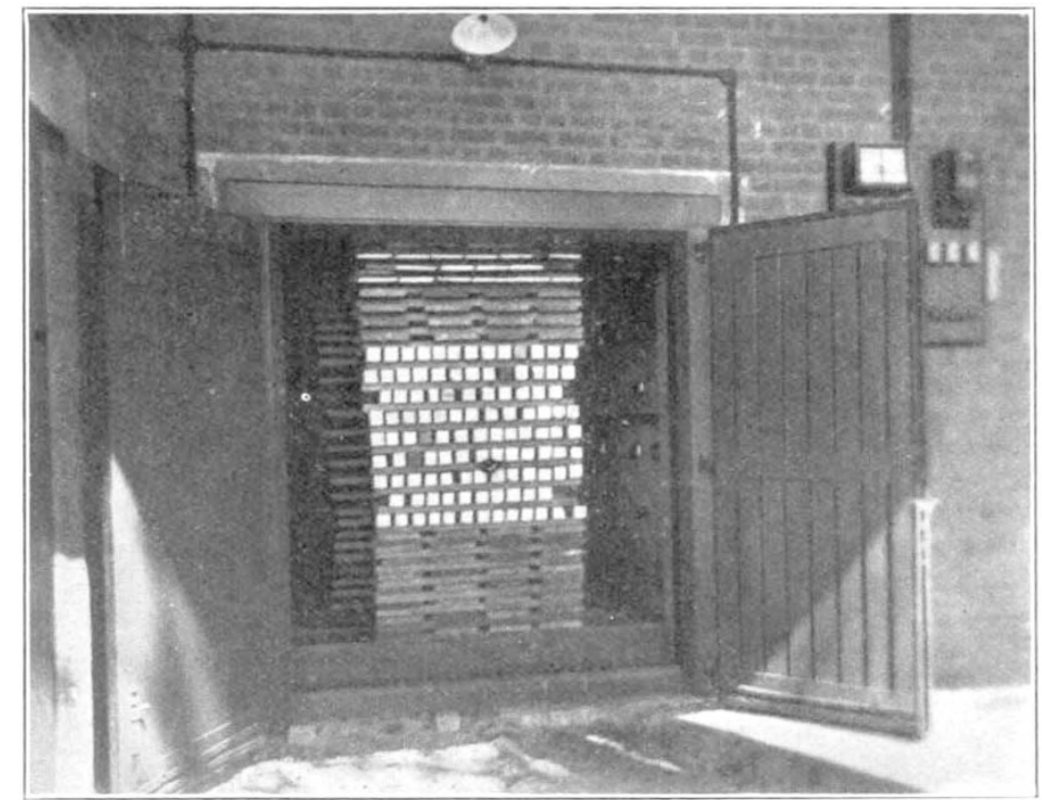

ntal Sturtevant kiln at the Forest Research Institute, Dchra Dun, showing timber stacked ready for seasoning.

In the Timber Testing Section more than 200,000 tests have been carried out during the last five years, and a great quantity of valuable data about all the more important Indian timbers has been collected. As examples of the results of tests made in the laboratories, the life of aeroplane wing spars in India was extended from five to seven years, and it is expected that local wood will be used on a large scale in the oil wells of Burma in place of the expensive imported hickory.

In a climate like that of India nothing can be more important for users of timber than to see that their wood is properly treated before it is made up. Experimental seasoning kilns have now been running for some years at Dehra Dun, and the best method of seasoning many important Indian timbers has been ascertained. As a result of the work done at Dehra Dun, the Gun Carriage and Rifle Factories and the Railway Board are installing batteries of kilns. The Forest Research Institute carried out most successfully seasoning operations on 1000 walnut rifle parts, seasoning them all in seven weeks instead of five years. Timber endures so many hardships in the fierce climate of India between the forest and the factory,

No. 3065, Vor. 122] 
that proper seasoning is of the utmost importance, and this is now being realised by timber users.

The most important work done in the Wood Preservation Section is in connexion with railway sleepers. It might appear that India would have no difficulty about the supply of railway sleepers, but this is far from being the case, and the supply of durable woods (such as deodar and teak) which resist white ants is insufficient. The Forest Research Institute has concentrated on treating sleepers of second class woods in such a way that they can be economically used to take the place of the more durable timbers. Success has been obtained, and several railways have built, or are building, plants to undertake the treatment of the cheaper Indian timbers. This will result in the profitable utilisation of millions of tons of second class woods, which would not otherwise find a market for years to come.

Bamboos cover very large areas in the Indian
The Wood-Working Section is a most important part of the economic branch. It receives large quantities of timber from all over India and Burma, and converts them to the sizes required for experimental work in all the other sections. In the section itself all the most important woods of India and Burma are used for carpentry, veneering, plywood, etc., and the volume of work in the section increases daily. Indian carpenters are being trained in large numbers in modern methods of wood-working. A modern sawmill deals with the logs, and a fully equipped machine-shop handles the output from the sawmill.

In considering the total export trade of India in forest products, it may be noted that the value of minor products exported considerably exceeds that of timber. The value of lac exported annually runs into millions of pounds. The section of the Forest Research Institute which deals with these products has never been properly manned. or equipped, and it is only now that properly organised investigation into many important products is being undertaken. The large majority of forest species yield something of use to man, and in Burma alone, where there are some 3000 woody plants, there is an immense field for investigation. Skilled modern treatment of the resin of one of the Indian pines in the Punjab and the Cnited Provinces has already resulted in India becoming largely self-supporting in the matter of turpentine. Among other forest products which offer profitable fields for scientific inquiry are gums, oils, cutch, fibres, tanning and dyeing materials, charcoal, drugs, spices, and fodder plants.

\section{Forest Botany.}

Systematic work and mycology take up most of the time of the officers of this branch. The mycologist has only just been ap. pointed, but already good progress has been made in investigating an important fungus on conifers.

FIG. 3.-Paper pulp experimental machine at the Forest Research Institute, Dehra Dun. forests, and the Forest Research Institute has done a great deal of work to prove that they can be profitably utilised in the form of paper pulp. Difficulties in digestion have been overcome through the skilled investigations of Mr. Raitt, who has also examined and reported on pulp propositions in the forest. As soon as the price of wood pulp rises, due to the exhaustion of supplies, bamboo will come into its own. It is believed that it may be found possible to use it for making artificial silk, and samples have been sent to England for trial.

The basis of all proper utilisation of timber is a knowledge of its structure, and this is especially the case in India, where there are so many different hard woods. Dr. Brown, of the University of Syracuse, U.S.A., was employed by the Government of India for a short period, and laid the foundations of the scientific study of the microseopical structure of Indian timbers. He published a "Manual of Indian Wood Technology " and is now training an Indian at Syracuse for the Institute. The Institute receives numerous specimens of wood with the request that they may be identified, and this can only be done by a highly trained wood technologist.
The preparation of floras and the management of the new arboretum come under this branch, and an important part of the work of the botanists is the determination of species. A surprising amount of incorrect information regarding the identity of plants is received from forest tracts.

\section{Forest ENTOMOLOGY.}

This, the first of the branches of the Forest Research Institute to be founded, is now a large and flourishing concern. The laboratories and insectary at the new Institute are spacious and up-to-date, and the collections are splendidly housed.

One of the most important subjects to which the officers of this branch have devoted themselves is the enormous damage done to the valuable Sal (Shorea robusta) forests of Central and Northern India by a beetle, and the measures devised for checking the damage have been most successful.

Systematic entomology plays an important part in all investigations. Defoliators and other pests attacking teak are under investigation, and all the more important species in India come under the consideration of the entomologists. The intimate

No. 3065, VoL. 122] 
connexion between science and profitable forestry is never lost sight of. Many minor pests are being studied, and help is given to all provinces in solving their problems.

\section{Chemistry.}

This is the smallest branch of the Forest Research Institute and its work is chiefly complementary to that of the others. It will be sufficient as an example to refer to the description of work on minor forest products given above, and it is easy to realise how important a part chemistry must play in the examina. tion of the problems they provide. The study of forest soils is carried on in association with the sylviculturist, and the analysis of mixtures used for preserving wood is another example of the activities of the branch.

\section{EDUCATION}

All the research officers take part in the instruction of the students at the Forest College as an important part of their duties. This applies not only to the members of the staff who specialise in entomology, botany, etc., but also to the experts in timber testing, wood-working, paper pulp, seasoning and wood preservation.

\section{Publicatrons.}

The results of the work done at the Forest Research Institute are published by the Government Press as soon as possible. Some 200 Records, Bulletins, etc., have appeared since 1905, as well as many manuals, floras, and volumes on other aspects of forestry.

\section{International Astronomical Union.}

\section{Lexden Meeting.}

$\mathrm{T}$ HE third ordinary general assembly of the International Astronomical Union was held at Leyden on July 5-13. It was by far the most representative meeting so far held, astronomers of twentyeight different countries being present. Incidentally, it was the largest gathering of astronomers ever held. During the meeting the adhesion of Rumania to the International Research Council and to the Astronomical Union was announced, increasing the total number of members to twenty-four. The close of the meeting left a very general hopefulness that before the next meeting of the Union most of the seven nations present as visitors for the first time (Germany, Austria, Hungary, Russia, China, Esthonia, Lithuania) would have become members of the Union.

The meeting opened with a reception by the Dutch government at the beautiful old Ridderzaal in The Hague. Addresses were delivered by His Excellency the Minister of Education, Arts and Sciences, the president of the Royal Academy of Sciences at Amsterdam, the Rector Magnificus of the University of Leyden, and the president of the International Astronomical Union (Prof. W. de Sitter, Director of the Leyden Observatory). The keynote of these addresses was one of gratification that under the auspices of neutral Holland the countries separated by the War had found it possible to come together again in the pursuit of science and the study of astronomy. Throughout the meeting, abundant hospitality was organised by the local committee, of which the efficient and active secretary was Dr. C. H. Hins, of the Leyden Observatory. Here we need only mention a trip to the Lake District near Haarlem, a most interesting tour round the reclaiming works by which within a generation the Zuider Zee is to be reclaimed and large stretches of country lost seven hundred years ago to be once more made fertile; a visit to the Frans Hals Museum at Haarlem, and various receptions and garden parties. Honorary degrees were conferred by the University of Leyden upon M. H. Deslandres, Director of the Paris-Meudon Observatories, and upon Dr. Küstner, late director of the Bonn Observatory. The latter was, unfortunately, prevented by ill-health from attending the meeting, and Dr. Guthnick acted as his proxy.

The main work of the Union was performed at the sessions of twenty-eight commissions. A few of the resolutions of general interest brought forward by the commissions and adopted by the Union may be referred to here. It was agreed to publish, with the help of Prof. Stroobant (Uccle), a list of observatories and astronomical staffs, and with the help of M. Delporte an atlas on a small scale with a list of arcs definitely fixing by hour circles and parallels of latitude the boundaries of the constellations. It was agreed to advise astronomers for the present not to use the term G.M.T. (Greenwich Mean Time), which changed its significance on Jan. 1, 1925, but to use for time reckoned from Greenwich Mean Midnight the term G.C.T. (Greenwich Civil Time), W.Z. (Weltzeit), or U.T. (Universal Time). The expression G.M.A.T. (Greenwich Mean Astronomical Time) should be used by anyone reckoning time from Greenwich mean noon.

The report of the Commission on Dynamical Astronomy contained an interesting statement by Prof. de Sitter of the terms required to convert Newtonian or uniform time to astronomical time given by the variable rotation of the earth. The Commission on Solar Physics, collaborating with a commission of the International Research Council on solar and terrestrial relationships, agreed on an index of solar activity. It was also agreed to urge on the Dutch government. the need of observing the total eclipse of May 9, 1929, visible in Sumatra, and on the Australian government the need of observing that eclipse and the eclipse of Oct. 22,1930 , visible in the island of Niuafou, in the Tonga protectorate. Further useful co-operation between eclipse observers of different countries was arranged, and a further study of the distribution of the continuous spectrum of the sun in the ultra-violet was urged. The growing importance of line spectrophotometry in the study of the sun's atmosphere was also recognised.

The Committee on Wave Lengths, for which Dr. Babcock had prepared a very valuable report, recommended a number of secondary standards of iron lines, and also a table of standards of solar wavelengths. Both of these were adopted by the Union. The most important problems in wave-length determination were also scheduled for immediate attention. The Commission on the Physical Observations of Planets urged further work on the absorption bands in planetary spectra and undertook to compile a catalogue for the names of Martian markings. The Commission on Lunar Nomenclature is nearing the end of its work of compiling a definitive catalogue of the markings on the moon. The Commission on Longitude Determination by Wireless reported that it would repeat the experiments of October 1926 about the year 1933, when the lessons of the previous experiments have been fully studied and steps taken to determine and eliminate systematic errors revealed in the previous work. The Committee on Variation of Latitude reported that a new latitude station in latitude $39^{\circ} \mathrm{N}$. would shortly be established at Kitab, near Samarkand, under the Uzbekistan-Soviet

No. 3065 , VoL. 122$]$ 